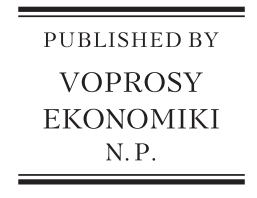

Russian Journal of Economics 7 (2021) 91-92

DOI 10.32609/j.ruje.7.71057

Publication date: 9 July 2021

Russian

Journal of

Economics

www.rujec.org

\title{
Introduction
}

\section{Economic history of Russia: New topics and approaches}

\author{
Leonid I. Borodkin* \\ Lomonosov Moscow State University, Moscow, Russia
}

This Russian Journal of Economics special issue is devoted to economic history, an interdisciplinary field at the intersection of history and economics. This field has been actively developing for more than half a century, and its successes were recognized by the Nobel Prize in Economics in 1993, which was awarded to Robert Fogel and Douglas North. The rationale for this decision of the Swedish Royal Academy included their great contribution to a "new economic history" (or cliometrics): "Their work has deepened our knowledge and understanding within fundamental areas of research, as to how, why and when economic change occurs... Fogel and North have thus in different ways renewed research in economic history, by making it more stringent and more theoretically conscious."1

The articles in this issue of the journal characterize the active development of economic history research in the $21^{\text {st }}$ century. The cliometric direction in its most pronounced form is represented in the work of Carol S. Leonard, Zafar Nazarov, Leonid I. Borodkin, Maria A. Karpenko, and Roman B. Konchakov. Their paper considers the influence of railroads construction on the dynamics of prices for agricultural land in Russia from 1860 to 1910 . The authors confirm the hypothesis that building of railroads in a particular area should lead to an increase in land prices in it (as was the case in European countries and the USA in the 19th century). This hypothesis was confirmed when using the database created by the authors, which includes data on the length of railway lines in 1894, land prices in 1910 and growth rate of those prices during the period 1885-1910 for each of the 50 provinces of European Russia.

The authors of the other four papers also gain verifiable knowledge, relying on relevant sources and quantitative methods of analysis. The range of problems considered is very wide, covering the period from the beginning of the $18^{\text {th }}$ century to the 1920 s.

\footnotetext{
* E-mail address: lborodkin@mail.ru

1 https://www.nobelprize.org/prizes/economic-sciences/1993/press-release/
} 
The article by Elena S. Korchmina and Paul Sharp provides a comparative analysis of the economic and institutional development of two seemingly dissimilar countries - Russia and Denmark - in the $18^{\text {th }}$ and $19^{\text {th }}$ centuries. The authors note that the two empires had similarities in a number of aspects, focusing on agriculture - due to its importance for both Danish and Russian economic history. The article examines the important role that the Danes played in modernizing reforms in pre-revolutionary Russia. The authors pay attention to the transfer of scientific knowledge and technology, and compare the level of inequality in both countries in the context of the fiscal institutions of both empires. Another aspect of the comparison is related to the increasing role of canals and, more broadly, waterways after Sweden's defeat in the Northern War, in promoting the market integration of Russia and Denmark in the Northern Baltic region.

Infrastructural aspects of agrarian market development in Russia in the second half of the 19th century are the subject of research by Sofya A. Salomatina and Vladislav Y. Ivakin who study the influence of commercial banks and railroads on the increase of agricultural production efficiency in the Central Black Earth region of the Russian Empire. The study provides a statistical analysis of data on the harvest of crops, the railroad transportation of grain and flour, and the annual volume of banking services to agricultural producers and sellers. The authors show that banking services in Russia in the late $19^{\text {th }}$ century were provided not only to commercial and industrial clientele and stock markets, as is still believed; instead, in those regions where agriculture dominated, the service infrastructure was focused on this sector.

Vadim M. Rynkov's article focuses on little-known aspects of the Civil War in the East of Russia, related to the regulation of the labor market by the antiBolshevik governments in 1918-1922. The author focuses on institutional factors, mechanisms, and results of this regulation, which operated in these years in the Urals, Siberia, and the Far East under the conditions of declining production, reduced commodity circulation, and growing instability of the labor market, which increased the transaction costs of hiring labor. To understand the political context of economic processes considered in the article, the author reminds us that after a short initial period of formation of temporary anti-Bolshevik governments in the east of the country, in November 1918 the power of the Supreme Ruler of Russia Admiral Alexander Kolchak and his Russian government was established, controlling then the whole East of Russia. The article shows that in contrast to the Bolshevik government, the military dictatorship of Kolchak used coercive measures on a limited scale and not effectively, showing a commitment to "liberal measures" of economic regulation.

Irina V. Shilnikova's article raises questions about the reasons for the high profitability of foreign concessions in the USSR in the 1920s-1930s, the mechanisms of their lending and the methods of the Soviet side aimed at restraining the growth of foreign concessionaires' profits. Despite the interest of the Soviet government in attracting foreign capital to rebuild the economy declared in the 1920s, most concessions did not last long and were liquidated before the end of the contract period. The author answers these questions by analyzing data from archival sources on textile concessions. 